\title{
Sorokiniol: a new enzymes inhibitory metabolite from fungal endophyte Bipolaris sorokiniana LK12
}

Liaqat Ali ${ }^{1+}$, Abdul Latif Khan ${ }^{1 * \dagger}$, Javid Hussain ${ }^{2}$, Ahmed Al-Harrasi ${ }^{1 *}$, Muhammad Waqas ${ }^{3,4}$, Sang-Mo Kang ${ }^{3}$, Ahmed Al-Rawahi ${ }^{1}$ and In-Jung Lee ${ }^{3^{*}}$

\begin{abstract}
Background: Medicinal plants harboring endophytic fungi could carry significant potential for producing bioactive secondary metabolites. Endophytic fungi serve as alternate source of interesting compounds in their natural and modified synthetic forms to treat different diseases. In this regard, endophytic microflora associated with alkaloid-rich medicinal plants Rhazya stricta is least known.

Results: We isolated one new bioactive compound sorokiniol (1) along with two known cyclic peptides BZR-cotoxin I (2) and BZR-cotoxin IV (3) from fungal endophyte Bipolaris sorokiniana LK12. The structures of the isolated new and known compounds were elucidated through spectroscopic data, including $1 \mathrm{D}$ and $2 \mathrm{D} N \mathrm{NMR}\left({ }^{1} \mathrm{H},{ }^{13} \mathrm{C}, \mathrm{HSQC}, \mathrm{HMBC}\right.$, and NOESY), mass, and UV. The known peptides (2-3) were characterized by ESI-MS, MS/MS, and by comparing the NMR data with the literature. The isolated metabolites were assayed for their role against enzyme inhibition. Compound 1 was significantly inhibitory towards acetyl cholinestrase while the other compounds (2-3) had moderate anti-lipid peroxidation and urease activities.
\end{abstract}

Conclusion: The present results suggest that the endophytic microorganism associated with indigenously important medicinal plants can offer a rich source of biologically active chemical constituents which could help in discovering enzyme inhibitory lead drugs.

Keywords: Endophytic fungi, Secondary metabolites, Bipolaris sorokiniana LK12, Cyclic peptides, Structure elucidation, Enzyme inhibition and antioxidant

\section{Background}

Endophytes (bacteria or fungi) reside in the internal tissues of plant at least once in their life cycle. This symbiosis can be oriented towards commensalism or mutualism between host and microbe. In this association, the plant provides a protective sanctuary and accessibility to nutrients, whereas, in return, the endophyte establishes a mutual relationship with host by imparting positive effects by regulating phytohormones and mineral nutrients [1]. The endophytic microorganisms secrete metabolites inside plant's tissues to improve tolerance against abiotic environmental stresses

\footnotetext{
*Correspondence: latifepm78@yahoo.co.uk; aharrasi@unizwa.edu.om; ijlee@knu.ac.kr 'Equal contributors

${ }^{1}$ UoN Chair of Oman's Medicinal Plants and Marine Natural Products, University of Nizwa, Nizwa 616, Sultanate of Oman

${ }^{3}$ School of Applied Biosciences, Kyungpook National University, Daegu

41566, Republic of Korea

Full list of author information is available at the end of the article
}

[2-5]. Various biologically active metabolites are produced by endophytic microorganisms such as alkaloids, steroids, flavonoids, peptides, azaphilones, terpenoids, and phenolics [5-7]. Schulz et al. [1] emphasized on the diversity of active chemical constituents ( $51 \%)$ from endophytic microbes in comparison with other soil microflora ( 38 \%). Currently, there have been many reports of bioactive natural products with significantly higher anticancer, insecticidal, and antimicrobial potentials from fungal endophytes [8].

One of the interesting examples is the production of paclitaxel (Taxol - an anticancer drug) from endophyte Pestalotiopsis microspora [9]. Such potential has increased the interest to search more numbers of novel metabolites from fungal endophytes $[3,10]$. In present work, Rhazya stricta was selected on the basis of its indigenous medicinal importance whilst to explore associated endophytic 
fungus and their ability to produce biologically active chemical constituents. Rhazya stricta wildly grows in various countries of Middle Eastern regions and South Asia. It is medicinally important plant and is famous for alkaloids contents [11]. Approximately, 100 different kinds of alkaloids are isolated from Rhazya stricta [12, 13]. Some of the chemical compounds isolated from this plant have been identified to possess strong potential in various pharmacological properties [13].

Rhazya stricta, being rich in wide array of chemical constituents, was selected with the aim to assess the symbiotic endophytic fungi and potential metabolites. The endophytic wealth has not been efficiently explored from Rhazya stricta. In a recent report we isolated fungal endophyte Bipolaris sorokiniana LK12 from the leaf parts of $R$. stricta [14]. This strain was characterized for the production of bipolarisenol - a new metabolite which is a derivative of radicinol. The metabolite was found to significantly inhibit the activities of urease and acetyl cholinesterase enzymes [14].

Looking at its metabolomics potential and bioactivities, we further continued the exploration of bioactive chemical compounds from this endophytic fungal strain. In this regards, current study was aimed to isolate and characterize biologically active chemical constituents produced from $B$. sorokiniana LK12 through advanced chromatographic and nuclear magnetic resonance spectroscopy techniques. The results revealed that a new secondary metabolite, sorokiniol (1), along with two known cyclic depsipeptides, BZRcotoxin I (2) and BZR-cotoxin IV (3) (Fig. 1), have been isolated whilst the chemical structures were elaborated through advanced spectral techniques. To understand any biological role of isolated metabolites, the compounds were assessed for their enzyme inhibition activities.

\section{Methods}

\section{Isolation, growth and molecular identification of} endophytic fungi

The fungal endophyte $B$. sorokiniana LK12, isolated from the leaf parts of Rhazya stricta was identified and grown as described in detail by Arnold et al. [15] and by
Khan et al. [14]. Briefly, the isolated fungus (RSL-1.2) was grown in seven liters of Czapek broth comprising peptone (1\%), glucose (1\%), $\mathrm{KCl}(0.05 \%), \mathrm{FeSO}_{4} \cdot 7 \mathrm{H}_{2} \mathrm{O}$ (0.001\%), $\mathrm{MgSO}_{4} .7 \mathrm{H}_{2} \mathrm{O}(0.05 \%)$, streptomycin (80 ppm) and $\mathrm{pH} 7.5 \pm 0.2$. The cultured fungus inoculated in liquid broth was grown on shaking incubator for twenty one days at $28{ }^{\circ} \mathrm{C}$. The broth was centrifuged $\left(5,000 x \mathrm{x}\right.$ at $4{ }^{\circ} \mathrm{C}$ for $10 \mathrm{~min}$ ) to separate the culture filtrate (CF) and mycelia (120.4 g). Approximately, one gram of fungal cells were lyophilized for DNA extraction, PCR analysis, and sequencing for identification.

The fungal DNA was extracted as described Khan et al. [14]. The fungus was identified through sequencing internal transcribed spacer (ITS) regions. A set of universal primers ITS-1 (5'-TCCGTAGGTGAACCTGCGG-3') and ITS-4 (5'-TCCTCCGCTTATTGATATGC-3') was also used to amplify through PCR. The PCR product was sequenced by Macrogen Inc. (Seoul, South Korea). The sequence obtained was BLASTn searched (NCBI) to compare the sequence homology of KL12 nucleotides and with that of related fungi using ITS regions. The homologous sequences were aligned using Clustal W (1.6) in MEGA 6.0 [16, 17]. A maximum parsimony tree was constructed. Bootstrap replications (1000) were used for nodes in phylogenetic tree. The sequence was submitted to NCBI GenBank for the accession number.

\section{Extraction and purification of compounds}

The mycelial cells (120.0 g) and culture filtrate (seven liters) were partitioned with equal amount of ethyl acetate at least three times. Both extracts were dried in vacuo and traces of water was removed by anhydrous sodium sulfate. The dried extract was further concentrated under reduced pressure to get $2.1 \mathrm{~g}$ of crude EtOAc extract. The silica gel column chromatography was performed on the ethyl acetate (EtOAc) extract by using various polarity ( $n$-hexane/ EtOAc) solvent system, which afforded 5 fractions; A to E. The fifth fraction (E) was further purified through a fully preparative recycling HPLC (High Performance Liquid Chromatography; JAI, Japan). A continuous flow rate of $3.5 \mathrm{~mL} / \mathrm{min}(6: 4$
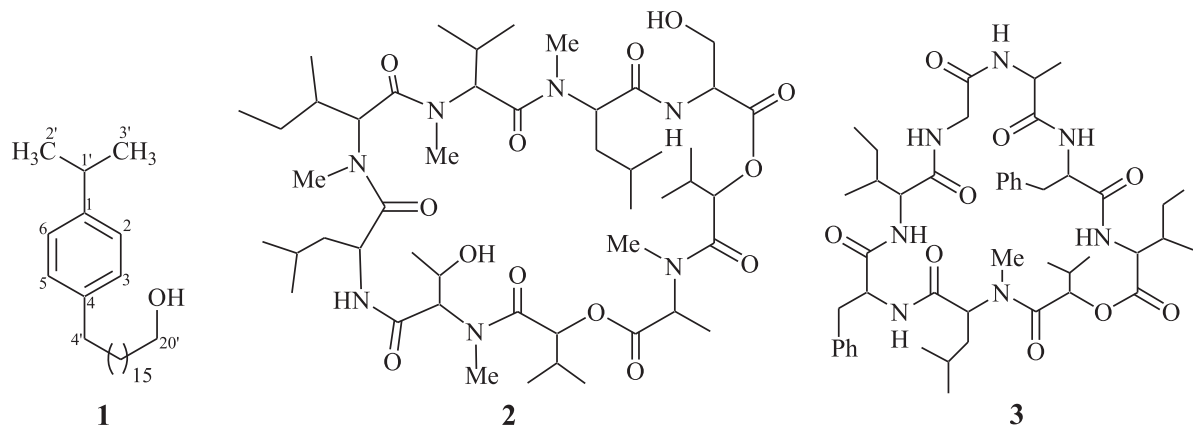

3

Fig. 1 Structures of the isolated compounds (1-3) from fungal endophyte Bipolaris sorokiniana LK12 
EtOAC/n-hexane) was maintained and compound 1 $(5.1 \mathrm{mg})$ was obtained at $23 \mathrm{~min}$ retention time with five recycles.

\section{Chromatography and spectroscopic techniques for identification}

The measurement of optical rotations was performed on a polarimeter (JASCO DIP 360). The IR spectra were obtained through ATR-Tensor 37 spectrophotometer by Bruker. To record the ESI mass spectra the QSTAR XL mass spectrometer by Applied Biosystems was used with a capillary voltage set from $5-5.5 \mathrm{kV}$. The NMR spectra $\left({ }^{1} \mathrm{H}\right.$ and $\left.{ }^{13} \mathrm{C}\right)$ were recorded on Bruker spectrometer operating at $600 \mathrm{MHz}\left(150 \mathrm{MHz}\right.$ for $\left.{ }^{13} \mathrm{C}\right)$. The $\delta$ values on the chemical shift scale are reported in $\mathrm{ppm}$, while the J values of the coupling constants are given in Hz. Purification of minor compounds was performed by recycling HPLC by using a 7:3 EtOAc/n-hexane solvent system in a silica gel column with a flow rate of $4 \mathrm{~mL} / \mathrm{min}$. Precoated aluminium silica gel sheets (60 F-254, Merck) were used for TLC (thin layer chromatography), which were visualized under UV light at 254 and $366 \mathrm{~nm}$. Ceric sulphate and ninhydrin reagent were used for spraying the TLC followed by heating.

\section{Identification of the metabolites}

The isolated metabolites were characterized by spectroscopic data (UV, IR, ${ }^{1} \mathrm{H}-\mathrm{NMR},{ }^{13} \mathrm{C}-\mathrm{NMR}, 2 \mathrm{D}$ NMR, ESI and MS/MS studies). Compound 1 was characterized as a new constituent, whereas compound 2 and 3 were identified as earlier reported BZR-cotoxin I and BZRcotoxin IV respectively. HR-EI-MS data showed that the molecular weight of chemical compound 1 was 374.3543 (calcd. for $\mathrm{C}_{26} \mathrm{H}_{46} \mathrm{O}$ 374.3549), whereas ESI-MS indicated the molecular weight of compound 2 as 968.6287 $[\mathrm{M}+\mathrm{H}]^{+}$(calcd. for $\mathrm{C}_{48} \mathrm{H}_{86} \mathrm{~N}_{7} \mathrm{O}_{13}, 968.6283$ ) and compound 3 as $876.5239[\mathrm{M}+\mathrm{H}]^{+}$(calcd. for $\mathrm{C}_{47} \mathrm{H}_{70} \mathrm{~N}_{7} \mathrm{O}_{9}$, 876.5244).

Compound 1: Pale yellow gummy solid (24.5 mg); m.p. 170-175 ${ }^{\circ} \mathrm{C},[\alpha]_{\mathrm{D}}^{30}+0.8^{\circ}\left(\mathrm{CHCl}_{3} ;\right.$ с 0.0013$)$ ); IR $v_{\max }$ $\left(\mathrm{CHCl}_{3}\right) 3400(\mathrm{OH}) ; 2922,1591$, and 1463 (aromatic functionalities); ${ }^{1} \mathrm{H}-\mathrm{NMR}\left(600 \mathrm{MHz}, \mathrm{CDCl}_{3}\right): \delta 7.21$ $(2 \mathrm{H}, \mathrm{d}, J=8.4 \mathrm{~Hz}), 6.94(2 \mathrm{H}, \mathrm{d}, J=8.4 \mathrm{~Hz}), 3.67(2 \mathrm{H}, \mathrm{m})$, $2.83(1 \mathrm{H}, \mathrm{m}), 2.27(2 \mathrm{H}, \mathrm{m}), 1.53-1.21(16 \mathrm{H}$, overlap signal), $1.29(14 \mathrm{H}, \mathrm{s}), 1.23(6 \mathrm{H}, \mathrm{d}, J=6.1 \mathrm{~Hz}) ;{ }^{13} \mathrm{C}-\mathrm{NMR}$ $\left(150 \mathrm{MHz}, \mathrm{CDCl}_{3}\right): \delta 148.7$ (C-1), $139.2(\mathrm{C}-4), 126.9(\mathrm{C}-$ 2, C-6), 117.2 (C-3, C-5), 56.9 (C-20'), 36.9 (C-4'), 32.4 (C-5'), 31.9 (C-1'), 30.9 (C-19'), 29.2 (C-6' to C-18'), 22.7 (C-2', C-3'); EI-MS $(m / z): 374\left[\mathrm{M}^{+}, 119\right.$ [M - side chain alcohol] ${ }^{+}$; HR-EI-MS ( $\mathrm{m} / z$ ): 374.3543 (calcd. for $\mathrm{C}_{26} \mathrm{H}_{46} \mathrm{O}$ 374.3549).

Compound 2: Colorless amorphous powder (4.9 mg); IR $v_{\max }\left(\mathrm{CHCl}_{3}\right) 3430(\mathrm{OH}) ; 2950,2890,1755,1670$, and $1645 ;{ }^{1} \mathrm{H}-\mathrm{NMR}\left(600 \mathrm{MHz}, \mathrm{CDCl}_{3}\right): \delta 8.11(1 \mathrm{H}, \mathrm{d}, J=$
$8.2 \mathrm{~Hz}, \mathrm{NH}), 7.28(1 \mathrm{H}$, br s, NH), $5.52(1 \mathrm{H}, \mathrm{d}, J=10.1 \mathrm{~Hz})$, $5.43(1 \mathrm{H}, \mathrm{d}, J=6.7 \mathrm{~Hz}), 5.14(1 \mathrm{H}, \mathrm{d}, J=10.7 \mathrm{~Hz}), 5.06(1 \mathrm{H}$, d, $J=10.4 \mathrm{~Hz}), 5.02(1 \mathrm{H}, \mathrm{d}, J=8.5 \mathrm{~Hz}), 4.86(2 \mathrm{H}, \mathrm{m}), 4.71$ $(1 \mathrm{H}, \mathrm{m}), 4.64(1 \mathrm{H}, \mathrm{m}), 4.23(1 \mathrm{H}, \mathrm{br} \mathrm{s}), 3.80(1 \mathrm{H}, \mathrm{br} \mathrm{s}), 3.57$ $(1 \mathrm{H}, \mathrm{dd}, J=9.8,5.8 \mathrm{~Hz}), 3.27(3 \mathrm{H}, \mathrm{s}), 3.12(3 \mathrm{H}, \mathrm{s})$, $2.93(3 \mathrm{H}, \mathrm{s}), 2.85(3 \mathrm{H}, \mathrm{s}), 1.39(3 \mathrm{H}, \mathrm{d}, J=6.7 \mathrm{~Hz})$, $1.25(3 \mathrm{H}, \mathrm{d}, J=6.4 \mathrm{~Hz}), 2.45-1.20(11 \mathrm{H}, \mathrm{m}), 1.07$ $(3 \mathrm{H}, \mathrm{d}, J=6.7 \mathrm{~Hz}), 1.20-0.86(28 \mathrm{H}, \mathrm{m}), 0.81(3 \mathrm{H}, \mathrm{d}$, $J=6.4 \mathrm{~Hz}), 0.73(3 \mathrm{H}, \mathrm{d}, J=6.7 \mathrm{~Hz}) ;$ HR-ESI-MS $(m / z)$ : $968.6287[\mathrm{M}+\mathrm{H}]^{+}$(calcd. for $\mathrm{C}_{48} \mathrm{H}_{86} \mathrm{~N}_{7} \mathrm{O}_{13}, 968.6283$ ).

Compound 3: Amorphous powder $\left(5.3 \mathrm{mg}\right.$ ); IR $\mathrm{v}_{\max }$ $\left(\mathrm{CHCl}_{3}\right)$ 3430, 2975, 2880, 1730, 1680, 1525; ${ }^{1} \mathrm{H}-\mathrm{NMR}$ $\left(600 \mathrm{MHz}, \mathrm{CDCl}_{3}\right): \delta 7.54(1 \mathrm{H}, \mathrm{br} \mathrm{s}, \mathrm{NH}), 7.38(1 \mathrm{H}, \mathrm{d}, J=$ $7.3 \mathrm{~Hz}, \mathrm{NH}), 7.35-7.17(11 \mathrm{H}, \mathrm{m}), 7.06(1 \mathrm{H}, \mathrm{d}, J=5.6 \mathrm{~Hz}$, $\mathrm{NH}), 7.00(1 \mathrm{H}$, br s, NH), $6.69(1 \mathrm{H}, \mathrm{d}, J=8.9 \mathrm{~Hz}, \mathrm{NH}), 4.85$ $(1 \mathrm{H}, \mathrm{d}, J=5.8 \mathrm{~Hz}), 4.72(1 \mathrm{H}, \mathrm{m}), 4.54(1 \mathrm{H}, \mathrm{t}, J=7.8 \mathrm{~Hz})$, $4.34(1 \mathrm{H}, \mathrm{dd}, J=7.0,7.3 \mathrm{~Hz}), 4.05-3.85(2 \mathrm{H}, \mathrm{m}), 3.78(1 \mathrm{H}$, $\mathrm{dd}, J=4.3,16.3 \mathrm{~Hz}), 3.68(1 \mathrm{H}, \mathrm{m}), 3.49-3.30(3 \mathrm{H}, \mathrm{m}), 3.24-$ $3.07(2 \mathrm{H}, \mathrm{m}), 3.02(3 \mathrm{H}, \mathrm{s}), 2.20-1.10(10 \mathrm{H}, \mathrm{m}), 1.03(3 \mathrm{H}, \mathrm{d}$, $J=7.0 \mathrm{~Hz}), 0.99(3 \mathrm{H}, \mathrm{d}, J=6.7 \mathrm{~Hz}), 0.90-0.85(12 \mathrm{H}, \mathrm{m}), 0.79$ $(3 \mathrm{H}, \mathrm{t}, J=7.3 \mathrm{~Hz})$; HR-ESI-MS $(\mathrm{m} / z): 876.5239[\mathrm{M}+\mathrm{H}]^{+}$ (calcd. for $\mathrm{C}_{47} \mathrm{H}_{70} \mathrm{~N}_{7} \mathrm{O}_{9}, 876.5244$ ).

\section{Enzyme inhibition assays and anti-lipid peroxidation}

The ethyl acetate extract and the three compounds were subjected for antioxidant and enzyme suppression assay. The inhibition potential of isolated compounds was evaluated by modified thio-barbituric acid reactive substances (TBARS) method [18]. The oxidation of liposome (phosphatidyl-choline, Sigma - Germany; $50 \mathrm{mg} \mathrm{ml}^{-1}$ ) was caused by a mixture $(0.200 \mathrm{ml})$ of iron chloride $\left(\mathrm{FeCl}_{3}\right.$, $1 \mathrm{mM})$ and potassium chloride $(\mathrm{KCl}, 300 \mathrm{mM})$ in the presence of the sample/compound $(0.050 \mathrm{ml})$. Ascorbate $(0.16 \mathrm{mM} ; 0.125 \mathrm{ml})$ was used to initiate the peroxidation. The reaction mixture was incubated at $37^{\circ} \mathrm{C}$ for $20 \mathrm{~min}$. Mixture of TBA (0.38 \%) and TCA $(0.750 \mathrm{ml} \mathrm{1.5:1} \mathrm{(v/}$ v) solution) was then added to the reaction mixture, and kept on $95{ }^{\circ} \mathrm{C}$ for half an hour. The appearance of pink color was read on ELISA microplate reader (xMark, BioRad, USA) at $535 \mathrm{~nm}$. A control without test sample was used and the experiment was repeated three times. The percent inhibition was measured using formula: (1- At/Ao) x 100; where At and Ao are the absorbance for sample, blank and standard after 30 min incubation.

The method of Golbabaei et al. [19] was used to assess the urease enzyme (EC 3.5.1.5) inhibition activities. Briefly, a $0.055 \mathrm{ml}$ urea $(100 \mathrm{mM})$ in phosphate buffer (0.01 M LiCl, $1.0 \mathrm{mM}$ EDTA, $0.01 \mathrm{M} \mathrm{K}_{2} \mathrm{HPO}_{4} .3 \mathrm{H}_{2} \mathrm{O}$, $\mathrm{pH}$ 8.2), $0.025 \mathrm{ml}$ Jack bean Urease (2 units/mL; Sigma, Germany), and various concentrations of the chemical compounds $(10-100 \mu \mathrm{g} / \mathrm{mL})$ were combined in the reaction mixture with incubation for $15 \mathrm{~min}$ in a 96-well plate at $37{ }^{\circ} \mathrm{C}$. The indophenol method was used to 
evaluate the urease inhibitory activity by measuring the ammonia production. The alkali reagent $(0.1 \% \mathrm{NaOCl}$, $0.070 \mathrm{ml}$ and $0.5 \%$ sodium hydroxide) and the phenol reagent $(0.045 \mathrm{ml}, 1 \% \mathrm{w} / \mathrm{v}$ phenol and $0.005 \% \mathrm{w} / \mathrm{v}$ sodium nitroprusside) were mixed in each well and the change in absorbance per minute was measured after $50 \mathrm{~min}$ at $630 \mathrm{~nm}$, by using ELISA microplate reader. All the experiments were repeated thrice and thiourea $(10-200 \mu \mathrm{g} / \mathrm{mL})$ was used as the standard inhibitor $(95$ $\pm 1.50 \%$ Inhibition). The percentage inhibition was calculated by $=100-\left(\mathrm{OD}_{\text {test }} / \mathrm{OD}_{\text {control }}\right) \times 100$.

Acetyl Cholinestrase Enzyme (AChE) inhibition was measured by using a marginal modification in Ingkaninan et al. method [20]. In this method the substrate acetylthiocholine iodide (ATCI, $15 \mathrm{mM}$ ) is hydrolysed enzymatically to produce thiocholine, which in turn reacts with Ellman's reagent (DTNB, $3 \mathrm{mM}$ ), which is measured at $412 \mathrm{~nm}$ in ELISA microplate reader. AChE enzyme used in the activity was obtained from electric eel (844 U/mg protein). The stock solutions of enzyme were kept at $-80{ }^{\circ} \mathrm{C}$. Tris- $\mathrm{HCl}$ buffer $\left(0.02 \mathrm{M} \mathrm{MgCl}_{2}\right.$ and $0.1 \mathrm{M} \mathrm{NaCl}$ ) was used to dissolve DTNB, whereas ATCI solution was made in deionized water.

A mixture of $20 \mu \mathrm{l}$ of $0.25 \mathrm{U} / \mathrm{ml}$ of AChE, $40 \mu \mathrm{l}$ of buffer $(50 \mathrm{mM}$ Tris $\mathrm{pH} 8.0$ ), and $100 \mu \mathrm{l}$ of DTNB were added along with $20 \mu \mathrm{l}$ of different concentrations of compounds to each well in 96-well plates. The plate was incubated at $25{ }^{\circ} \mathrm{C}$ for $15 \mathrm{~min}$. The absorbance of the reaction mixture was read at $412 \mathrm{~nm}$ in ELISA spectrophotometer (xMark BioRad, USA). The negative control did not had sample in the assay mixture. To start the reaction, $20 \mu \mathrm{l}$ of ATCI was added to assay mixture and the rate of hydrolysis in acetylthiocholine read every $2 \mathrm{~min}$ for $20 \mathrm{~min}$. All the reactions were performed thrice and Galanthamine was used as the positive control and similar percentage inhibition formula was used mentioned earlier for urease enzyme.

\section{Statistical analysis}

The values shown are the mean of three replicates. Linear regression analysis were performed with $\mathrm{p}$ values ranged to 0.05 . Graphical representations were done by using GraphPad Prism software 6.01 package (GraphPad Software, Inc., CA, USA).

\section{Results and discussion}

\section{Endophyte identification and screening bioactivity}

Endophytic fungus RSL-1.2 was identified by gDNA extraction, PCR sequencing and amplification of ITS regions. The phylogenetic analysis of RSL-1.2 was carried out by using MEGA 6.0. With the help of neighbor joining (NJ) and maximum parsimony (MP) methods a consensus cladogram was established using $20 \quad$ (19 references and 1 clone) homologues ITS sequences. During BLASTn search, RSL-1.2 represented the highest sequence homology, query coverage, and lowest $\mathrm{E}$ values with $B$. sorokiniana. In dendrogram, RSL-1.2 formed a $99 \%$ bootstrap level of support with $B$. sorokiniana (Fig. 2). The aligned ITS sequence was deposited in the

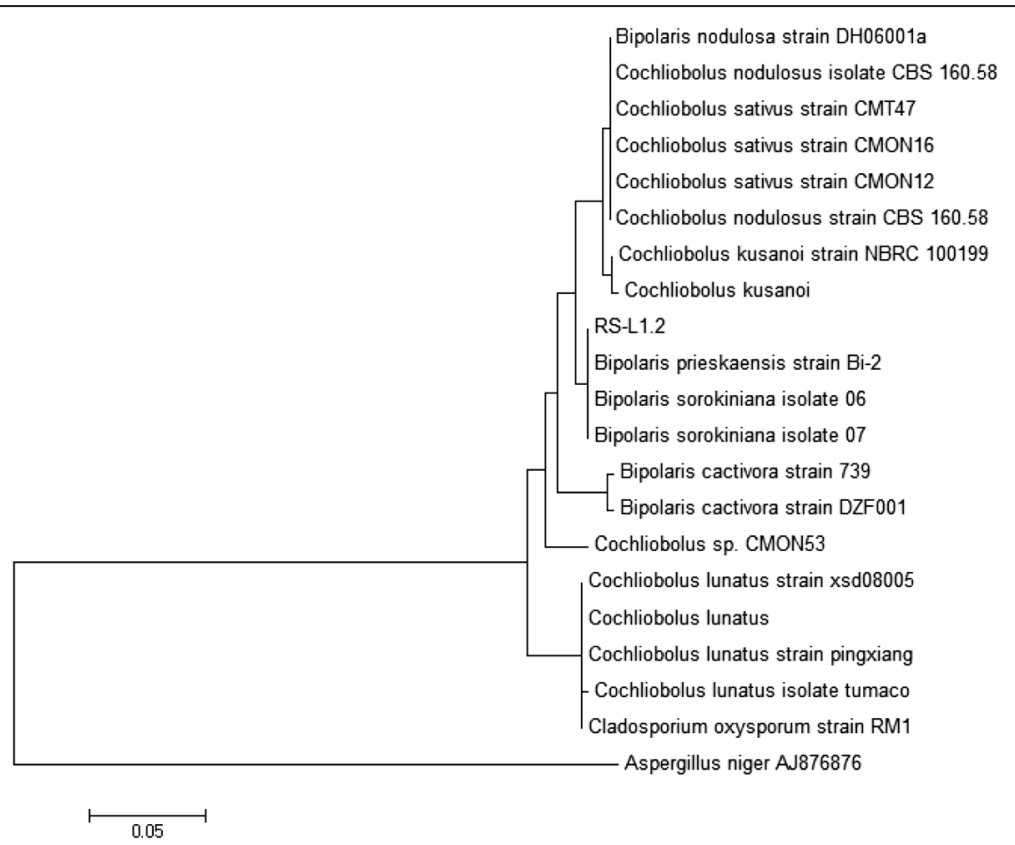

Fig. 2 Phylogenetic analysis of the ITS rDNA sequence of RSL-1.2 isolated from leaves of R. stricta. The analysis showed $99 \%$ sequence homologies with Bipolaris sorokiniana. Aspergillus niger was used as an out-group 
NCBI GenBank for an accession no. KP715347 as B. sorokiniana LK12 strain.

The EtOAc extract of the fungus $B$. sorokiniana LK12 was assessed for its antioxidant capacity using anti-lipid peroxidation, ABTS and superoxide anion radical scavenging activities. The results shown that the extract exhibited strong radical (superoxide anion and ABTS) scavenging potential in comparison to control (Additional file 1). The anti-lipid peroxidation activity was moderate as compared to the control.

\section{Isolation and structural elucidation of secondary metabolites}

Looking at the bioactive potentials of the EtOAc extract of endophyte, it was subjected to chromatographic studies to isolate bioactive secondary metabolites which yielded three compounds (1-3). Compound 1 was obtained in the form of pale yellow gummy solid by repeated chromatography experiments while using methanol/ethyl acetate (5\%) in a silica gel column. The molecular formula was established as $\mathrm{C}_{26} \mathrm{H}_{46} \mathrm{O}$ on the basis of EI-MS $\left(\mathrm{M}^{+}\right.$at $\mathrm{m} / z$ 374), along with the information obtained through ${ }^{13} \mathrm{C}$-NMR spectra of compound 1 (Additional file 2). The molecular formula $\mathrm{C}_{26} \mathrm{H}_{46} \mathrm{O}$ was further confirmed through high resolution mass spectrum (HR-MS), which showed the molecular ion peak of 1 at $\mathrm{m} / z \quad 374.3543$ (calcd. for $\mathrm{C}_{26} \mathrm{H}_{46} \mathrm{O}$ 374.3549). The ${ }^{1} \mathrm{H}-\mathrm{NMR}$ spectrum of compound 1 exhibited two signals for two protons each at $\delta 6.94(\mathrm{~d}, J=$ $8.4 \mathrm{~Hz}, 2 \mathrm{H})$ and $7.21(\mathrm{~d}, J=8.4 \mathrm{~Hz}, 2 \mathrm{H})$. These coupling constants along with the multiplicities of the aromatic protons indicated the para-substitution of benzene ring in compound 1. An upfield doublet for six protons at $\delta$ $1.23(\mathrm{~d}, J=6.1 \mathrm{~Hz}, 6 \mathrm{H})$ and a multiplet for one proton at $\delta 2.83(\mathrm{~m}, 1 \mathrm{H})$ were indicative of the presence of isopropyl substituent at benzene ring. The second substituent was in the form of a long chain alcohol, which was confirmed by the combined MS and NMR spectral data. The down field multiplet at $\delta 3.67(\mathrm{~m}, 2 \mathrm{H})$ was assigned to the methylene moiety directly attached to hydroxyl group, whereas the signal appeared at $\delta 2.27(\mathrm{~m}, 2 \mathrm{H})$ was assigned to the methylene group adjacent to benzene ring. The other methylene groups in the chain appeared between $\delta 1.53$ and 1.21 including a singlet at $\delta$ $1.29(\mathrm{~s}, 14 \mathrm{H})$. The length of the chain was further confirmed by the fragments appearing in EI-MS at $\mathrm{m} / z$ 31, $45,59,73,87,101,115,129,143,157,171,185,199$, $213,227,241$, and 255 . Similarly, the presence of isopropyl group and the para-substituted benzene ring was confirmed through fragments at $m / z 43,76$, and 119.

${ }^{13} \mathrm{C}$-NMR spectra of compound 1 (BB, DEPT) indicated the presence of two signals for two $\mathrm{sp}^{2}$ carbons each at $\delta 117.2,126.9$, two quaternary carbons at $\delta 139.2$ and 148.7, an upfield signal for two methyls at $\delta 22.7$, a methine signal at $\delta 31.9$, and signals for seventeen methylene, including a downfield signal at $\delta 56.9$, thus supporting the para-substituted benzene ring with isopropyl group and an alcoholic long chain substituent. These assignments were further confirmed by HMBC interactions (Fig. 3) and the structure was finally confirmed as sorokiniol (1), after the producing organism $B$. sorokiniana. Biosynthetically, compound 1 is similar in structure to urushiol class of compounds belonging to the plants of anacardiaceae family in the genus toxicodendron [21]. The biosynthesis of urushiols involves the decarboxylation and hydroxylation reactions of anacardic acid which is the product of extension of three malonyl-CoA units with palmitoleoyl-CoA followed by reduction and aldol cyclization [22].

Compound 2 was isolated from the crude extract through repeated column chromatography in semi-pure form. Further purification was done by recycling HPLC using 7:3 EtOAc/n-hexane with a flow rate of $4 \mathrm{ml} / \mathrm{min}$ after three recycles at an elution time of $21.3 \mathrm{~min}$. Compound 2 was isolated in semi-pure form at a range of $65 \%$ to $75 \%$ ethyl acetate/ $n$-hexane system from the crude extract through repeated column chromatography. Further purification was done by recycling HPLC using $7: 3$ ethyl acetate $/ n$-hexane with a flow rate of $4 \mathrm{ml} / \mathrm{min}$ after three recycles at an elution time of $21.3 \mathrm{~min}$. The structure of compound 2 was elucidated by the combined spectroscopic analyses including ESI-MS and NMR spectroscopy. The molecular formula of secondary

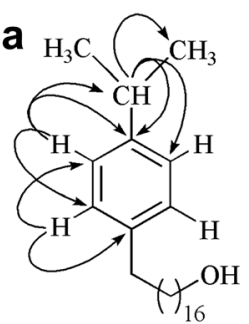

HMBC Interactions

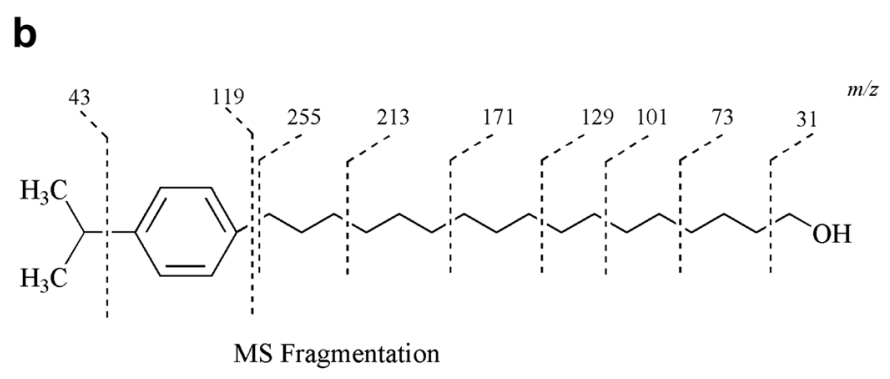

Fig. 3 Key HMBC Interactions (a) and Major Mass Fragmentations (b) in Compound 1 
metabolite 2 was established as $\mathrm{C}_{48} \mathrm{H}_{85} \mathrm{~N}_{7} \mathrm{O}_{13}$ by HRESI-MS on the basis of pseudo-molecular ion peak at $m / z \quad 968.6287 \quad[\mathrm{M}+\mathrm{H}]^{+}$(calcd. for $\mathrm{C}_{48} \mathrm{H}_{86} \mathrm{~N}_{7} \mathrm{O}_{13}$, 968.6283). Moreover, the major linear peptide (Fig. 4) was produced by the cleavage of ester bond between serine amino acid and 2-hydroxy-3-methylbutanoic acid. This linear peptide produced a main series of adjacent $y_{n}$ peaks at $m / z 868,783,683,568,455,328$, 215 , and 88 corresponding to the successive losses of 2-hydroxy-3-methylbutanoic acid, $\mathrm{N}$-methylalanine, 2hydroxy-3-methylbutanoic acid, $N$-methylthreonine, leucine, $N$-methylisoleucine, $N$-methylvaline, and $N$ methylleucine, respectively. Similarly, $b_{n}$ ions were detected at $m / z 101,186,401$, and 754 .

All these results suggested the sequence of amino acids for the linearized peptide ion derived from BZRcotoxin I and thus confirmed the structure 2 for the cyclic depsipeptide. Compound 2 showed two amide protons and five downfield methyl signals in ${ }^{1} \mathrm{H}-\mathrm{NMR}$ spectrum, whereas, nine signals for carbonyl groups were observed in ${ }^{13} \mathrm{C}$-NMR spectrum. The sequence of peptides in the molecule was further confirmed by the $\mathrm{HMBC}$ analysis.

The ${ }^{13} \mathrm{C}$-NMR of 2 showed 48 carbon signals which was in correlation with molecular formula, $\mathrm{C}_{48} \mathrm{H}_{85} \mathrm{~N}_{7} \mathrm{O}_{13}$. The DEPT experiment revealed the multiplicities while HMQC experiments suggested the attachments of the assigned protons. Specific resonances for peptides were observed in ${ }^{1}$ H-NMR spectrum of compound 2 in the form of broad singlets at $\delta 7.97$ and $7.33 \mathrm{ppm}$, which were assigned to amide $\mathrm{NH}$ protons. The peptide $\alpha$ protons appeared in the form of doublet of doublet and in some cases in the form of multiplets between $\delta 3.19$ and $4.79 \mathrm{ppm}$. The upfield signals in the region $\delta 0.81$ to 1.27 were assigned to the methyl groups of amino acids whereas the methyl groups connected with amide nitrogen appeared between $\delta 2.81$ and 3.36. Furthermore, the purified product had nearly identical physical and spectral properties as those of the reported cotoxin-I, which was previously reported to be produced by Bipolaris zeicola race 3 [23].

Compound 3 was also isolated in semi-pure form from the crude extract through repeated column chromatography at $80 \%$ to $90 \%$ ethyl acetate $/ n$-hexane system.
The final purification was obtained through recycling HPLC using 7:3 EtOAc/n-hexane with a flow rate of $4 \mathrm{ml} / \mathrm{min}$ after three recycles at an elution time of $25.4 \mathrm{~min}$. The structure of compound 3 was elucidated by combined ESI-MS and NMR spectral analysis. Pseudo molecular ion peak of the protonated molecule $[\mathrm{M}+\mathrm{H}]^{+}$ was observed at $m / z 876.5239$ (calcd. for $\mathrm{C}_{47} \mathrm{H}_{70} \mathrm{~N}_{7} \mathrm{O}_{9}$, 876.5244) which was helpful to determine the molecular formula $\mathrm{C}_{47} \mathrm{H}_{69} \mathrm{~N}_{7} \mathrm{O}_{9}$ for compound 3. The major linear peptide (Fig. 5) was produced by the cleavage of ester bond between isoleucine amino acid and 2-hydroxy-3methylbutanoic acid. This linear peptide produced a main series of adjacent $y_{n}$ peaks at $m / z 776,649,502$, $389,332,261$, and 114 corresponding to the successive losses of 2-hydroxy-3-methylbutanoic acid, $\mathrm{N}$-methylleucine, phenylalanine, isoleucine, glycine, alanine, and phenylalanine, respectively. Similarly, $b_{n}$ ions were detected at $m / z 101,228,375,488,545,616$, and 763 .

All these results suggested the sequence of amino acids for the linearized peptide ion derived from BZRcotoxin IV and thus confirmed the structure 3 for the cyclic depsipeptide. The ${ }^{1} \mathrm{H}$-NMR spectrum of 3 showed six amide protons and one downfield methyl singlet. Characteristic peptide resonances included broad singlets at $\delta 7.31$ and $7.89 \mathrm{ppm}$, which were assigned to amide $\mathrm{NH}$ protons. Additional signals in the aromatic region were assigned to the benzene ring of phenylalanine amino acids. The peptide $\alpha$ protons appeared in the form doublet of doublet and in some cases in the form of multiplets between 3.92 and $4.79 \mathrm{ppm}$.

In correlation with the molecular formula $\mathrm{C}_{47} \mathrm{H}_{69} \mathrm{~N}_{7} \mathrm{O}_{9}$, the ${ }^{13} \mathrm{C}-\mathrm{NMR}$ spectrum of compound 3 contained resonances for 47 carbons including eight signals for the carbonyl groups in the downfield region. The DEPT analysis suggested the multiplicities of carbon resonances while HMQC analysis showed the assignments of attached protons. The sequence of amino acids in the peptide was further confirmed through HMBC experiments. Based on the above discussion and the comparison of the physical and spectral data with those reported in literature, compound 3 was thus confirmed as cotoxin-IV, which was earlier reported to be produced by Bipolaris zeicola race 3 [24].

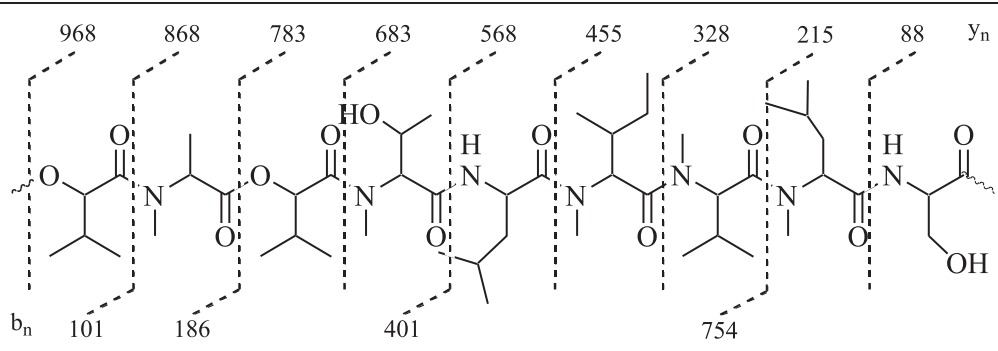

Fig. 4 Fragmentation Pattern of Protonated BZR-cotoxin I (2) 


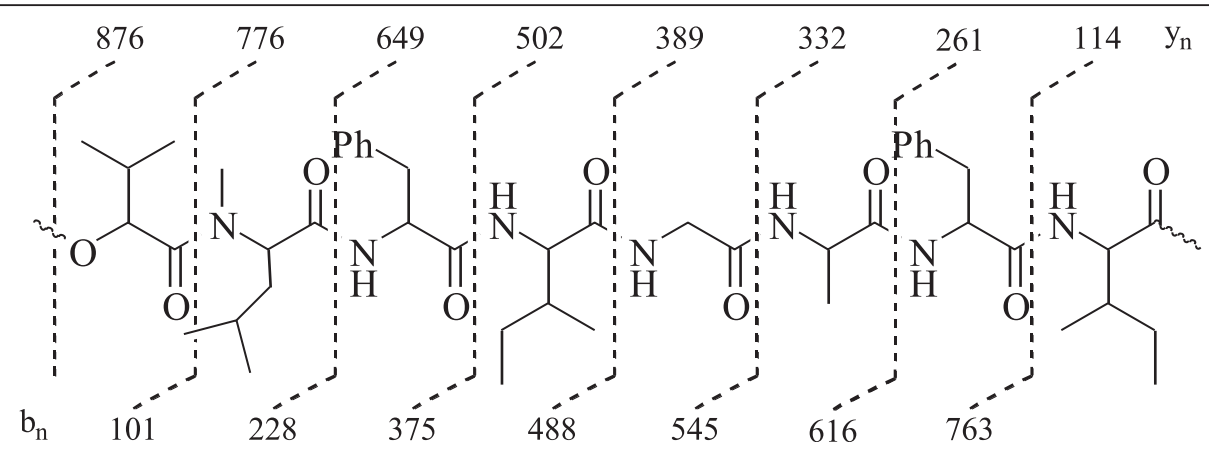

Fig. 5 Fragmentation Pattern of Protonated BZR-cotoxin IV (3)

\section{Enzyme inhibitive potential of secondary metabolites}

The purified compounds $1-3$ were subjected to bioassays against acetyl cholinesterase (AChE) and urease enzyme inhibition whilst these were also assessed for their anti-lipid peroxidation potential. Using a concentration gradient, compound 1 and 2 exhibited significantly higher AChE enzyme inhibition as compared to compound 3 (Fig. 6). The $\mathrm{EC}_{50}$ activity for compound 1 was $3.402+0.08 \mu \mathrm{g} / \mathrm{mL}\left(\mathrm{R}^{2}=0.89\right)$ using linear regression curve fitting with $\mathrm{EC}_{50}$ Shift in Graphpad Prism. Compound 3 showed a dose-dependent response against AChE enzyme inhibition. In case of urease enzyme inhibition, only compound 1 showed $50 \%$ inhibition at maximum concentration whilst other compounds ( 2 and 3) did not suppressed the enzyme activity (Fig. 7). A similar pattern of low level of anti-lipid peroxidation activity was shown by compound 3 (Fig. 8). The current results conclude that the three compounds exhibit significant AChE enzyme inhibition pattern.

Previously, there was no report of enzyme inhibition activity of bioactive metabolites isolated from $B$. sorokiniana LK12, however, a wide majority of fungal endophytes from various plants have been reported to play a vital role against

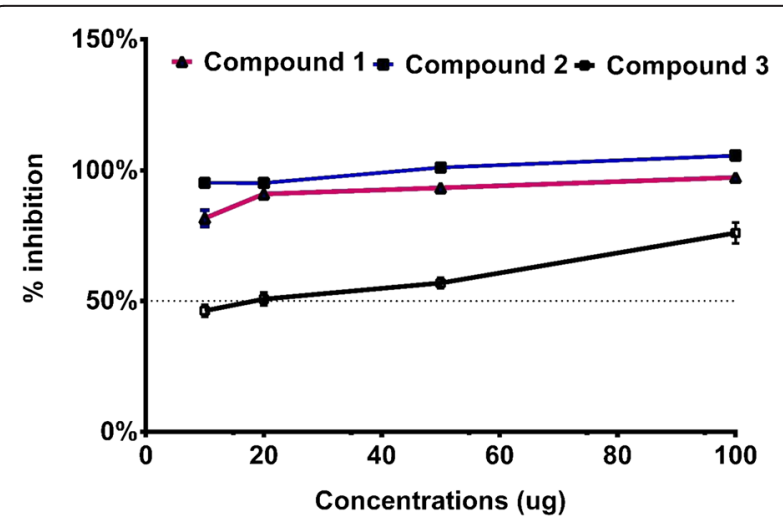

Fig. 6 Enzyme Acetyl Cholinesterase inhibition activities of compound $1-3$. The graphical lines shows standard error of means of three replications suppression of enzymatic disorders. Antioxidant activities are frequently investigated for endophytes (e.g., Botryosphaeria dothidea and Aspergillus awamori) isolated from medicinal plants (Melia azedarach L. and Rauwolfia serpentina Benth, respectively) $[8,25]$. Liu et al. [26] isolated Xylaria sp. from the stem of ancient medicinal plant Ginkgo biloba and studied the potential of this species to produce antioxidants, where the organism exhibited a strong radical scavenging activity. Similarly, Huang et al. [27] investigated the total antioxidant and total phenolic contents of a repository of 292 endophytes from 29 traditional Chinese medicinal plants using improved ABTS methods. Similarly, Rodrigues et al. [28] and Xiao et al. [29] suggested various endophytic fungi from different host plants can show potent source of essential enzyme inhibition activities such as AChE inhibition.

On the other hand, alzheimer's disease, for which AChE inhibition emerged as the major therapeutic target, only approved drug is galantamine [28]. We used this to compare our results, which were very encouraging; however, further studies at molecular level would be needed to get more insight of receptors involved in the inhibition of AChE [29]. The present results also

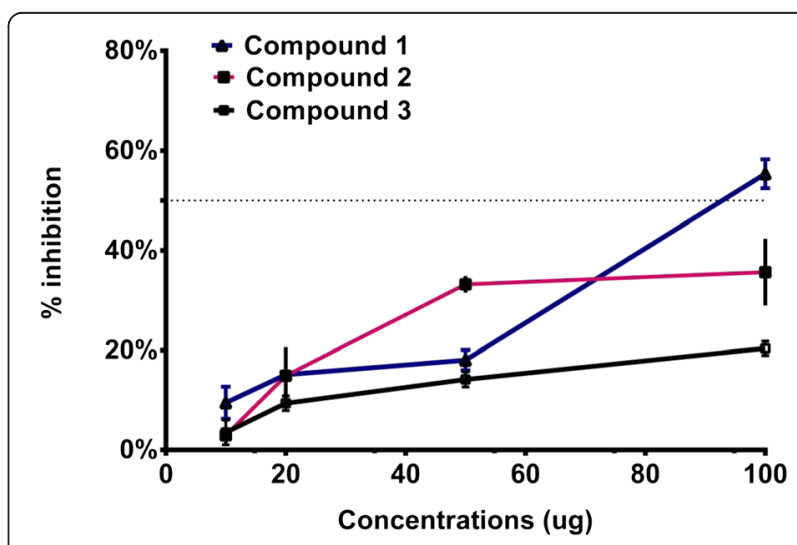

Fig. 7 Enzyme Urease inhibition activities of compound $1-3$. The graphical lines shows standard error of means of three replications 


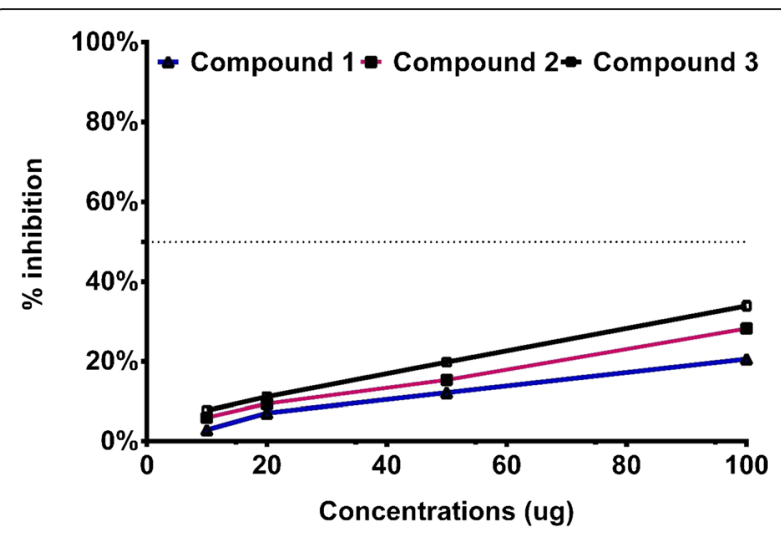

Fig. 8 Anti-Lipid Peroxidation activities of compound $1-3$. The graphical lines shows standard error of means of three replications

suggest that the endophytic microorganism of biologically active medicinal plants also carries interesting bioactivities which could help in discovering lead drugs.

\section{Conclusion}

The present results showed that fungal endophyte associated with medicinal plants can possess a potent ability to secrete biologically active metabolites. In current case, $B$. sorokiniana LK12 produced a new compound, sorokiniol along with two known cyclic peptides BZR-cotoxin I and BZR-cotoxin IV. The chemical constituents exhibited significantly inhibitory effects towards acetyl cholinestrase while moderate urease and anti-lipid peroxidation activities. Further studies at broader enzyme kinetics level could further help in understanding the enzyme inhibitory role of chemical constituents isolated from endophytes.

\section{Additional files}

Additional file 1: Figure S1. Antioxidant activity of the ethyl acetate extract $(1.0 \mathrm{mg} / \mathrm{mL})$ of the $B$. sorokiniana LK12. ABTS, LPO - anti-lipid peroxidation; $\mathrm{O}_{2}$ - superoxide anion. Bars shows standard error of five replicates of each activity. For positive control, ascorbic acid was use. (DOC $824 \mathrm{~kb}$ )

Additional file 2: Figure S2. Nuclear Magnetic Resonance spectroscopic analysis of compound 1-3. (PDF $333 \mathrm{~kb}$ )

\section{Abbreviations}

AChE, acetyl cholinestrase; DDW, deionized distilled water; HPLC, recycling preparative High Performance Liquid Chromatography; ITS, culture medium (culture filtrate-CF), internal transcribed regions; MP, maximum parsimony; $\mathrm{NJ}$, neighbor joining; PDA, potato dextrose agar; TBARS, thiobarbituric acid reactive substances; TLC, thin layer chromatography

\section{Acknowledgements}

The authors acknowledge the efforts of Khadija Al-Hosni and Salima Al-Khiziri for isolating the microorganism.

\section{Funding}

This work was financially supported by National Research Foundation of Korea (NRF), Ministry of Science, ICT and Future-Planning through BasicScience Research Program (2014R1A1A2A10058022) and The Oman Research Council (FURAP Program).

\section{Availability of data and materials}

Data supporting the findings is contained within the manuscript. Phylogenetic analysis of the ITS rDNA sequence of RSL-1.2 isolated from leaves of $R$. stricta. The gDNA sequence of Bipolaris sorokiniana LK12 was submitted to NCBI and are available under the accession No KP715347. The phylogenetic tree of LK12 fungal strain was deposited in TreeBase (ID: 19351). The strain is available on request with ALK at Biotechnology \& Microbiology lab, UoN Chair of Oman's Medicinal Plants \& Marine Natural Products, University of Nizwa, 616, Nizwa, Sultanate of Oman.

\section{Authors' contributions}

LA and ALK designed, and performed the experiments, while SMK, and MW undertook endophyte identification and phylogenetic analysis. JH, AA and AA edited the work. IJL and AA financially supported the work. All authors read and approved the final manuscript.

\section{Competing interests}

The authors declare that they have no competing interests.

\section{Consent to publish}

Not applicable.

Ethics approval and consent to participate

Not applicable.

\section{Author details}

'UoN Chair of Oman's Medicinal Plants and Marine Natural Products, University of Nizwa, Nizwa 616, Sultanate of Oman. ${ }^{2}$ Department of Biological Sciences and Chemistry, College of Arts and Sciences, University of Nizwa, Birkat Al-Mouz, Nizwa 616, Sultanate of Oman. ${ }^{3}$ School of Applied Biosciences, Kyungpook National University, Daegu 41566, Republic of Korea. ${ }^{4}$ Department of Agriculture, Abdul Wali Khan University, Mardan, Pakistan.

Received: 22 March 2015 Accepted: 1 June 2016

Published online: 09 June 2016

\section{References}

1. Schulz B, Boyle C, Draeger S, Römmert K, Krohn K. Endophytic fungi: a source of novel biologically active secondary metabolites. Mycol Res. 2002;106:996-1004.

2. Guo B, Wang $Y$, Sun $X$, Tang K. Bioactive natural products from endophytes: a review. Appl Biochem Microbiol. 2008:44:136-42.

3. Kusari S, Hertweck C, Spiteller M. Chemical ecology of endophytic fungi: origins of secondary metabolites. Chem Biol. 2012;19(7):792-8.

4. Li XJ, Zhang Q, Zhang AL, Gao JM. Metabolites from Aspergillus fumigates, an endophytic fungus associated with Melia azedarach, and their antifungal, antifeedant, and toxic activities. J Agric Food Chem. 2012;60(13):3424-31.

5. Khan AL, Hussain J, Al-Harrasi A, Al-Rawahi A, Lee IJ. Endophytic fungi: a source of gibberellins and crop resistance to abiotic stress. Crit Rev Biotech. 2013:35(1):62-74.

6. Schulz B, Boyle C. The endophytic continuum. Mycol Res. 2005;109:661-86.

7. Kaul S, Gupta S, Ahmed M, Dhar MK. Endophytic fungi from medicinal plants: a treasure hunt for bioactive metabolites. Phytochem Rev. 2012;11(4):487-505.

8. Xiao J, Zhang Q, Gao YQ, Tang JJ, Zhang AL, Gao JM. Secondary metabolites from the endophytic Botryosphaeria dothidea of Melia azedarach and their antifungal, antibacterial, antioxidant, and cytotoxic activities. J Agric Food Chem. 2014;62(16):3584-90.

9. Tan RX, Zou WX. Endophytes: a rich source of functional metabolites. Nat Prod Rep. 2001;18:448-59,

10. Strobel G, Daisy B, Castillo U, Harper J. Natural products from endophytic microorganisms. J Nat Prod. 2004;67:257-68.

11. Zaman K, Perveen S, Muzaffar A, Choudhary MI, Pervin A. Alkaloids from Rhazya stricta. Phytochemistry. 1991;30:1285-93.

12. Gilani SA, Kikuchi A, Shinwari ZK, Khattak ZI, Watanabe KN. Phytochemical, pharmacological and ethnobotanical studies of Rhazya stricta Decne. Phytother Res. 2007:4:301-7.

13. Ali BH, Al-Qarawi A, Bashir AK, Tanira M. Phytochemistry, pharmacology and toxicity of Rhazya stricta Decne: A review. Phytother Res. 2000;14:229-34. 
14. Khan AL, Ali L, Hussain J, Rizvi TS, Al-Harrasi A, Lee IJ. Enzyme inhibitory Radicinol Derivative from Endophytic fungus Bipolaris sorokiniana LK12, Associated with Rhazya stricta. Molecules. 2015;20(7):12198-208.

15. Arnold AE, Lutzoni F. Diversity and host range of foliar fungal endophytes: are tropical leaves biodiversity hotspots? Ecology. 2007;88(3):541-9.

16. Torres MS, White Jr JF, Zhang X, Hinton DM, Bacon CW. Endophytemediated adjustments in host morphology and physiology and effects on host fitness traits in grasses. Fungal Ecol. 2012;5:322-30.

17. Tamura K, Peterson D, Peterson N, Stecher G, Nei M, Kumar S. MEGA5: Molecular evolutionary genetics analysis using maximum likelihood, evolutionary distance, and maximum parsimony methods. Mol Biol Evol. 2011;28:2731-9.

18. Gulati V, Harding $\mathbb{H}$, Palombo EA. Enzyme inhibitory and antioxidant activities of traditional medicinal plants: Potential application in the management of hyperglycemia. BMC Comp Alter Med. 2012;12:77.

19. Golbabaei S, Bazl R, Golestanian S, Nabati R, Omrany RB, Yousefi B, et al. Urease inhibitory activities of $\beta$-boswellic acid derivatives. DARU J Pharm Sci. 2013;21:2

20. Ingkaninan K, Temkitthawon P, Chuenchom K, Yuyaem T, Thongnoi W. Screening for acetylcholinesterase inhibitory activity in plants used in Thai traditional rejuvenating and neurotonic remedies. J Ethnopharmacol. 2003:89:261-4

21. Barceloux DG. Medical Toxicology of Natural Substances: foods, fungi, medicinal herbs, plants, and venomous animals. NJ Hoboken eds: John Wiley \& Sons; 2008.

22. Dewick PM. Medicinal Natural Products: A Biosynthetic Approach, 2nd eds. New Jersey, USA: John Wiley \& Sons; 2002.

23. Ueda K, Xiao J-Z, Doke N, Nakatsuka S-I. Structure of BZR-cotoxin I Produced by Bipolaris zeicola race 3, the Cause of Leaf Spot Disease in Corn. Tet Lett. 1994;35:7033-6.

24. Ueda K, Xiao J-Z, Doke N, Nakatsuka S-I. Isolation and Structure of BZR-cotoxin IV produced by Bipolaris zeicola race 3 , the cause of leaf spot disease in corn. Tet Lett. 1995:36:741-4.

25. Nath A, Chattopadhyay A, Joshi SR. Biological activity of endophytic fungi of Rauwolfia serpentina Benth: an ethnomedicinal plant used in folk medicines in Northeast India. Proc Nat Acad Sci, India Sect B: Biol Sci. 2015;85(1):233-40.

26. Liu X, Mingsheng D, Chen X, Jiang M, Liu C, Yan G. Antioxidant activity and phenolics of an endophytic Xylaria sp. from Ginkgo biloba. Food Chem. 2007:105:548-54.

27. Huang WY, Cai YZ, Xing J, Corke H, Sun M. A potential antioxidant resource: endophytic fungi from medicinal plants. Econ Bot. 2007;61:14-30

28. Rodrigues KF, Costa GL, Carvalho MP, Epifanio RDA. Evaluation of extracts produced by some tropical fungi as potential cholinesterase inhibitors. World J Microbiol Biotech. 2005;21:1617-21.

29. Xiao ZE, Huang H, Shao C, Xia X, Ma L, Huang X, et al. Asperterpenols A and $B$, new sesterterpenoids isolated from a mangrove endophytic fungus Aspergillus sp. 085242. Org Lett. 2013;15:2522-5.

\section{Submit your next manuscript to BioMed Central and we will help you at every step:}

- We accept pre-submission inquiries

- Our selector tool helps you to find the most relevant journal

- We provide round the clock customer support

- Convenient online submission

- Thorough peer review

- Inclusion in PubMed and all major indexing services

- Maximum visibility for your research

Submit your manuscript at wuw biomedcentral.com/submit

CBiomed Central 